\title{
Economic Study on Farming Systems and its Effects on Income and Employment Generation in District Kanpur Nagar of Uttar Pradesh
}

\author{
Bhanu Pratap Singh ${ }^{1 *}$, Birendra Kumar ${ }^{1}$, Anshul Singh ${ }^{2}$ and Manoj Kumar ${ }^{1}$ \\ ${ }^{1}$ Department of Agricultural Economics and Statistics, ${ }^{2}$ Department of Soil Science and \\ Agricultural Chemistry, Chandra Shekhar Azad University of Agriculture and Technology, \\ Kanpur - 208001, Uttar Pradesh, India \\ *Corresponding author
}

\section{A B S T R A C T}

\section{Keywords}

Employment generation, Farming system, Income, Cost and return, Farmers

\section{Article Info}

Accepted: 26 July 2020 Available Online: 10 August 2020
The present investigation was under taken to work out income and employment generation under existing farming systems in Kanpur district of Uttar Pradesh during 2017-18. Two blocks namely- Bilhaur \& Sarsaul selected purposely for the study purposes. A total sample of 100 farmers (50 farmers from each block) consisting of 54 marginal, 29 small and 17 medium farmers were selected randomly for the study. These farmers were grouped according to the land holdings they possess, that are marginal farmer's (0-1 hectare) and small farmer's (1-2 hectare) and medium farmers (2-3 ha). Main farming systems were existed in the areas of Kanpur district viz. Crops + dairy + vegetables, Crops + dairy + poultry, Crops + dairy + goatery, Crops + dairy + beekeeping and Crops + dairy + piggery. The findings revealed that Farming system (crops + dairy + vegetables) fetches highest net income at all size group of farms. This farming systems fetched out on average income of Rs. 86500.18/ha at marginal Rs. 96392.78/ha at small and Rs. 107306.19/ha at medium size group of farms while crop + dairy + poultry system ranked lowest in the study area. The high employment generation was found in case of crop + dairy + vegetable farming system (281-man days/year), followed by Crops + dairy + poultry enterprise combination (249.67-man days/year) and very least in case of crops + dairy + bee-keeping farming system (225.33 days). The highest employment days was generated through crops followed by vegetables, dairy, poultry, piggery, goatery, bee-keeping. The status of employment was maximum at medium group of farmers followed by small and marginal groups.

\section{Introduction}

Farming system is more or less stable arrangement of farming activities managed by a household. Farming system that are ecologically, biologically and socioeconomically, should not only involved crop production but are also dependent upon their integration with other enterprises like animal husbandry, horticulture, vegetable production, piggeries, fisheries, apiculture goatery, poultry, sericulture and agro-forestry. The concept of farming system takes case of the component like soil, water, crops, livestock, 
labour and other resources available with farm families. The best strategy for economic viability is flexibility with in agriculture system for production of milk and their products food, fodder, fiber, fuels, eggs and fisheries etc. The enterprise flexibility can be achieved through reduced input cost and increased diversification of activities providing more and more employments.

A farming system is a farming pattern or combination of farming activities practiced on a farm. It is a production system that provides an opportunity for farmers to exploit the full productive potential of their farm through the optimal use of ecological and economic resource over a longer time frame. Role of farming system approach are increased productivity per unit of land, better utilization of resource, recycling of farm wastes, sustainability, employment generation and reduction of risk.

A farming system is the result of complex interaction among a number of inter dependent components to achieve it an individual farmer allocates certain quantities and qualities of the four factors of production namely, land labour capital and management to which he has access. Kumar and Jam (2002).

In traditional crop livestock farming system, the crop residues are led to the livestock and the dung is used as manure or fuel, but due to population pressure and increased fuel demand now-a-days majority of the cattle dung is consumed as fuel. If the biogas technology is introduced in the system the organic matter (dung and other wastes) can used both as manure and fuel. Dung and farm wastes can be used to produce biogas and the resulting slurry is enriched manure. In crop livestock system, the particular cropping sequence and proportionate size and composition of livestock population have to be determined on the basis of resource base and farming situation. It is possible to develop many such systems involving piggery, mushroom cultivation, commercial fishery, orchards, etc. in accordance with the available resources and complementarily among the enterprises. The poultry droppings can be used as pig feed. Pig excreta can be used for biogas production. The biogas sludge can be used for mushroom cultivation and growing fish in the pond. Sediments of the fish pond and bio-gas sludge can be used for manuring the orchard. The farming system to be followed is unique for a farm or a particular group of farms, which has to be developed through target-oriented location.

\section{Materials and Methods}

The investigation was conducted during 201718 in district Kanpur nagar. A multi stage simple random sampling technique was adopted to select the district, block, villages and farmers. A list of all development blocks of the district Kanpur Nagar was prepared. Among the 10 development blocks of district Kanpur Nagar. Two blocks namely- Bilhaur \& Sarsaul selected purposively for the study purposes. A list of all villages participating the different farming system in block Bilhaur $\&$ Sarsaul was prepared. Out of this, five villages from each block \& a total of 10 villages were selected randomly for the study purpose. A total number of 100 farmers (50 farmers from each block) were selected randomly from the universe of 10 villages ( 5 villages of each block) on the proportion of the farmer's falling in each village under different size group of farms. These farmers were grouped according to the land holdings they possess, that are marginal farmer's (0-1 hectare) and small farmer's (1-2 hectare) and medium farmers (2-3 ha).

The enquiry was conducted by survey method. The data were collected by personal 
interview with selected vegetable growers on well prepared schedules. The tabular analysis, weighted average, costs and return analysis have been worked out for analyzing the different data.

The enquiry was conducted by survey method. The data were collected by personal interview with the selected farmers on wellprepared schedules. During the investigation, several visits were made from time to time to collect the information keeping in view the convenience of the farmers.

The information was collected by using the local language for interview. To ensure the accuracy and reliability of the information every possible care was taken.

The helps of Village Development Officers, were taken for obtaining correct and reliable data. The secondary data were collected from published materials, journals books, records of block Tehsil and district head quarter, district statistical records and records of Lekhpal etc.

\section{Components of farming system}

There are five main components of system in district Kanpur Nagar. Crop + dairy is very popular farming practiced in study area but farmers are used to go for system Crops + Dairy + Vegetable, Crops + Dairy + Poultry, Crops + Dairy + Goat rearing, Crops + Dairy + Bee Keeping, Crops + Dairy + Piggery in the different parts of the study area.

\section{Results and Discussion}

The input and return, level of net income and the level of employment of different farming system have been worked out for measuring the farm economy. The results obtained from the present investigation have been discussed in the following sub heads.

\section{Inputs and return of different farming} system

The Table -1 shows that the farmers of the study area were doing with different combination of enterprise mix or farming systems. The enterprise analysis of different farming systems reflect that the vegetable farming is very-very remunerative enterprise among all because vegetables crops fetched out highest net incomes over all components of farming systems. Among vegetable crops tomato reflects maximum net returns of Rs. 96871.61/ha. on medium farms followed by small and marginal farms. On return front crops enterprise ranks second, dairy ranked third, goatery ranked fourth, piggery ranked fifth, beekeeping was on sixth and poultry enterprise was on seventh position at the farmers field of the study area.

\section{Level of net incomes from different farming systems}

The Table -2 shows that, highest average net incomes income of Rs. 86500.18/ha at marginal, Rs. 96392.78/ha at small and Rs. $107306.19 /$ ha at medium size group of farms were achieved through crops + dairy + vegetable farming systems followed by crops + dairy + goatery farming systems at all threesize group of farms. The crops + dairy + piggery was 3rd remunerative farming systems followed by fourth rank of crops + dairy + beekeeping and crops + dairy + poultry have the $\mathrm{V}^{\text {th }}$ position in the prevailing faring systems in the study area.

\section{Employment from different enterprises}

The Table -3 presented the status of employment days generated from different enterprise at the different size group of farms. The highest employment days was generated through crops followed by vegetables, dairy, poultry, piggery, goatery, bee-keeping. 
Table.1 Inputs and return of different farming system (in Rs.)

\begin{tabular}{|c|c|c|c|c|c|c|c|c|c|}
\hline \multirow[t]{2}{*}{ Particulars } & \multicolumn{3}{|c|}{ Marginal } & \multicolumn{3}{|c|}{ Small } & \multicolumn{3}{|c|}{ Medium } \\
\hline & Input & Output & $\begin{array}{c}\text { Net } \\
\text { income }\end{array}$ & Input & Output & $\begin{array}{c}\text { Net } \\
\text { income }\end{array}$ & Input & Output & $\begin{array}{c}\text { Net } \\
\text { income }\end{array}$ \\
\hline \multicolumn{10}{|l|}{ Crops } \\
\hline Paddy/ha & 7396.66 & 5.3872 .00 & 16475.34 & 41282.80 & 57009.60 & 15726.80 & 42785.93 & 58992.80 & 16206.87 \\
\hline Wheat/ha & 41685.06 & 54600.00 & 12914.94 & 42292.05 & 57390.00 & 15097.95 & 43435.71 & 62030.00 & 18594.29 \\
\hline \multicolumn{10}{|l|}{ Vegetables } \\
\hline Okra/ha & 59973.37 & 102855.80 & 42882.43 & 64373.19 & 111425.40 & 47052.21 & 70179.19 & 122096.20 & 51917.01 \\
\hline Cauliflower/ha & 52966.07 & 116884.50 & 63918.43 & 58373.44 & 127890.00 & 69516.56 & 60083.59 & 130993.00 & 70909.41 \\
\hline Tomato/ha & 78243.96 & 151350.50 & 73106.54 & 84927.81 & 167386.10 & 82458.29 & 96866.99 & 193738.60 & 96871.61 \\
\hline Brinjal/ha & 66817.03 & 118961.92 & 52144.89 & 76713.22 & 140069.12 & 64355.90 & 80246.67 & 154082.56 & 73835.89 \\
\hline $\begin{array}{l}\text { Vegetable } \\
\text { pea/ha }\end{array}$ & 66291.16 & 137857.00 & 71565.84 & 73536.82 & 155889.58 & 82352.76 & 80001.48 & 172810.42 & 92808.94 \\
\hline \multicolumn{10}{|l|}{ Dairy } \\
\hline Per cow & 18404.36 & 23192.00 & 7229.65 & 19193.14 & 23998.00 & 7361.12 & 20012.37 & 24830.00 & 7485.97 \\
\hline Per buffalo & 29866.84 & 44800.00 & 14933.16 & 31358.60 & 47664.00 & 16305.40 & 32883.88 & 50672.00 & 17788.12 \\
\hline \multicolumn{10}{|l|}{ Poultry } \\
\hline Per 5 birds & 2919.38 & 3990.00 & 1070.62 & 3068.75 & 4474.38 & 1405.63 & 3388.75 & 4950.75 & 1562.00 \\
\hline \multicolumn{10}{|l|}{ Goatery } \\
\hline Per Goat & 6876.38 & 9814.50 & 2938.12 & 7202.88 & 11781.75 & 4578.87 & 7993.87 & 13723.50 & 5729.63 \\
\hline \multicolumn{10}{|l|}{ Bee Keeping } \\
\hline Per box & 3907.34 & 6160.00 & 2252.66 & 3989.92 & 6650.00 & 2660.08 & 4148.22 & 7135.00 & 2986.78 \\
\hline \multicolumn{10}{|l|}{ Piggery } \\
\hline Per Pig & 13738.50 & 16500.00 & 2761.50 & 14189.30 & 18290.00 & 4100.70 & 14778.00 & 20090.00 & 5312.00 \\
\hline
\end{tabular}


Table.2 Average level of net incomes (Rs.) from different farming systems

\begin{tabular}{|l|c|c|c|}
\hline Combination/Farming Systems & Marginal & Small & Medium \\
\hline Crops + dairy + vegetables & 86500.18 & 96392.78 & $\mathbf{1 0 7 3 0 6 . 1 9}$ \\
\hline Crops + dairy + poultry & 26847.17 & 28651.27 & $\mathbf{3 1 5 9 9 . 6 2}$ \\
\hline Crops + dairy + goatery & 28714.67 & 31824.51 & $\mathbf{3 5 7 6 7 . 2 5}$ \\
\hline Crops + dairy + beekeeping & 28029.21 & 29905.72 & $\mathbf{3 3 0 2 4 . 4 0}$ \\
\hline Crops + dairy + piggery & $\mathbf{2 8 5 3 8 . 0 5}$ & $\mathbf{3 1 3 4 6 . 3 4}$ & $\mathbf{3 5 3 4 9 . 6 2}$ \\
\hline
\end{tabular}

Table.3 Employment from different enterprises (days)

\begin{tabular}{|l|c|c|c|}
\hline Particulars & Marginal & Small & Medium \\
\hline Crops & 155 & 172 & $\mathbf{1 7 8}$ \\
\hline Vegetables & 62 & 70 & $\mathbf{7 5}$ \\
\hline Dairy & 38 & 45 & $\mathbf{4 8}$ \\
\hline Poultry & 35 & 38 & $\mathbf{4 0}$ \\
\hline Goatery & 16 & 18 & $\mathbf{2 0}$ \\
\hline Bee Keeping & 12 & 13 & $\mathbf{1 5}$ \\
\hline Piggery & 18 & 22 & $\mathbf{2 5}$ \\
\hline Total days & $\mathbf{3 3 6}$ & $\mathbf{3 7 8}$ & $\mathbf{4 0 1}$ \\
\hline
\end{tabular}

Table.4 The level of employment on different component of farming systems (days)

\begin{tabular}{|l|c|c|c|c|c|}
\hline \multicolumn{1}{|c|}{ Combination } & Marginal & Small & Medium & Average & \\
\hline Crops & 155 & 172 & 178 & 168.33 & I \\
\hline Dairy & 38 & 45 & 48 & 43.67 \\
\hline Vegetables & 62 & 70 & 75 & 69.00 \\
\hline Total & $\mathbf{2 5 5}$ & $\mathbf{2 8 7}$ & $\mathbf{3 0 1}$ & $\mathbf{2 8 1 . 0 0}$ & \\
\hline Crops & 155 & 172 & 178 & 168.33 & II \\
\hline Dairy & 38 & 45 & 48 & 43.67 \\
\hline Poultry & 35 & 38 & 40 & 37.67 \\
\hline Total & $\mathbf{2 2 8}$ & $\mathbf{2 5 5}$ & $\mathbf{2 6 6}$ & $\mathbf{2 4 9 . 6 7}$ & \\
\hline Crops & 155 & 172 & 178 & 168.33 & III \\
\hline Dairy & 38 & 45 & 48 & 43.67 & \\
\hline Goat rearing & 16 & 18 & 20 & 18.00 & \\
\hline Total & $\mathbf{2 0 9}$ & $\mathbf{2 3 5}$ & $\mathbf{2 4 6}$ & $\mathbf{2 3 0 . 0 0}$ & \\
\hline Crops & 155 & 172 & 178 & 168.33 & IV \\
\hline Dairy & 38 & 45 & 48 & 43.67 \\
\hline Bee Keeping & 12 & 13 & 15 & 13.33 \\
\hline Total & $\mathbf{2 0 5}$ & $\mathbf{2 3 0}$ & $\mathbf{2 4 1}$ & $\mathbf{2 2 5 . 3 3}$ & \\
\hline Crops & 155 & 172 & 178 & 168.33 \\
\hline Dairy & 38 & 45 & 48 & 43.67 \\
\hline Pig rearing & 18 & 22 & 25 & 21.67 \\
\hline Total & $\mathbf{2 1 1}$ & $\mathbf{2 3 9}$ & $\mathbf{2 5 1}$ & $\mathbf{2 3 3 . 6 7}$ & \\
\hline
\end{tabular}


The status of employment was maximum at medium group of farms followed by small and marginal groups

\section{Level of employment on different} component of farming systems

The Table -4 represent that the average highest level of employments (281 days) was generated through crops + dairy + vegetable farming system followed by crops + dairy + poultry farming systems(249.67) days and 233.67 days from Crops + dairy + pig rearing. The crops + dairy + goat rearing provided 230 days of employment rank forth in the enterprise combination. Lowest employment (225.33 days) generation was observed through crops + dairy + bee-keeping farming system approach in the study area. Similar results were confirmed by Rai and Tiwari (2011), Singh et al., (2004).

\section{Constraints and policy implementations to farming system}

During course of study different type of constraints observed at different farmers level which hampered the actual growth in yield, income and employment opportunities in the study area. The main constraints faced by farmers are given below:

Lack of proper dissemination of technical know, how and management packages of different component of farming systems.

Lack of improved seeds of High Yielding Varieties of different crops.

Less availability of improved seeds of vegetable crops like bhindi, cauliflower, tomato etc.

Less availability of irrigation water specially resource poor small and marginal farmers.

Less knowledge about proper application and balance use of fertilizer.
Lack of improved breeds of milch animals, poultry birds, goats and pigs.

Lack of knowledge about maintenance of potential cross breed milch animals.

Lack of proper and scientific maintenance of poultry, goatery. piggery arid beekeeping.

Lack of proper knowledge about farming system approaches and assurance through this system.

Lack of proper and efficient marketing system for better price margin at post-harvest periods.

Less employment opportunities throughout year in crop husbandry due to very' small average land holding and prevalence of marginal and small farmers.

Less risk bearing capacity to resource poor farming community for combining different enterprises with crop husbandry.

Some social issues resist the farmers (Especially higher caste farmers) to rear the piggery or poultry enterprises which is really advantageous with lower intake of capital and labour.

Lack of knowledge, profit and assurance of different enterprise mix their complementary, supplementary and symbiotic approach for better income employment and optimum resource use.

\section{Suggested suitable strategies to overcome} the different constraints faced by the farmers during study period, these are given below

Educating to the farmers about latest technologies and management practices of different components of farming systems.

Availing improved seeds of high Yielding Varieties of different crops and seeds and seedlings of different vegetable 
crops in the study area.

Ensuring irrigation facilities to the small and marginal farmers through state tube wells or subsidized pumping sets.

Educating farmers about soil health and time1 application of balance fertilization. Availing NPK fertilizers at the sowing time through cooperative societies.

Availing improved breeds of milch animals, poultry birds, goat, pigs, beekeeping etc. at subsidized rates with maintenance input resources.

Educating farmers about different profitable farming systems suited to their beauty and their concrete advantage for assured income and employment generation throughout year.

Innovate the farmer about efficient marketing system to sale their produce directly to consumers rather involvement of different market intermediaries.

To promote farming system through availing of different input resource and to encourage farmer to intensify/diversify their crop enterprise combining some supplementary enterprise like dairy, poultry, goatery, apiary etc. for higher yield, incomes and employment.

To educate farmers about minimum risk through enterprise mix rather one enterprise, with higher yield income and continuous employment throughout year.

\section{References}

Kumar Shalander and Jam, D.K. (2002). Interactions and changes in farming systems in semi-arid parts of India: Some issues in sustainability. Agric. Eco. Res. Rev., 15 (2): 2 17-230.

Rai, J., Tiwari, U.S. (2011). Economic evaluation of different farming systems in district Lucknow of Uttar Pradesh. Agriculture Update, 6(1): 129-132.

Singh, S.N., Singh, K.P., Kadiyan, V.S. and Hasija, R.C. (2004). Employment generation for small and marginal farmers through various farming systems in Haryana. Haryna J. Agron., 20 (1): 93-95.

\section{How to cite this article:}

Bhanu Pratap Singh, Birendra Kumar, Anshul Singh and Manoj Kumar. 2020. Economic Study on Farming Systems and its Effects on Income and Employment Generation in District Kanpur Nagar of Uttar Pradesh. Int.J.Curr.Microbiol.App.Sci. 9(08): 3397-3403.

doi: https://doi.org/10.20546/ijcmas.2020.908.392 